\title{
Characterization of $\mathrm{MPP}^{+}$secretion across human intestinal Caco-2 cell monolayers: role of P-glycoprotein and a novel $\mathrm{Na}^{+}$-dependent organic cation transport mechanism
}

\author{
${ }^{1}$ Kelly Bleasby, ${ }^{1}$ Seema Chauhan \& *,1 Colin D.A. Brown \\ ${ }^{1}$ Department of Physiological Sciences, The Medical School, University of Newcastle-upon-Tyne, Newcastle-upon-Tyne, NE2 \\ $4 \mathrm{HH}$
}

1 In the kidney, a number of transport proteins involved in the secretion of permanently charged organic cations have recently been cloned. To evaluate the possible similarities between intestine and kidney in the handling of organic cations we investigated the transport of 1-methyl-4phenylpyridinium $\left(\mathrm{MPP}^{+}\right.$) across monolayers of intestinal Caco-2 cells. $\mathrm{MPP}^{+}$is a prototypic substrate of the cloned organic cation transporters hOCT1 and hOCT2.

2 In Caco-2 cell monolayers, the basolateral to apical flux of $\mathrm{MPP}^{+}$was significantly greater than the apical to basolateral flux, consistent with net secretion of $\mathrm{MPP}^{+}$.

3 Net secretion of $\mathrm{MPP}^{+}$was abolished by addition of either $10 \mu \mathrm{M}$ cyclosporin $\mathrm{A}$ or $100 \mu \mathrm{M}$ verapamil to the apical membrane. In contrast, secretion of $\mathrm{MPP}^{+}$was unaffected by addition of either TEA $(2 \mathrm{mM})$ or decynium-22 $(2 \mu \mathrm{M})$ to either apical or basolateral membranes. These results suggest that $\mathrm{MPP}^{+}$secretion is mediated primarily by $\mathrm{P}$-glycoprotein located at the apical membrane. We found no evidence of a role for hOCT1 or hOCT2 in the secretion of MPP ${ }^{+}$.

4 In addition to net secretion of $\mathrm{MPP}^{+}$, we found evidence of a $\mathrm{Na}^{+}$-dependent $\mathrm{MPP}^{+}$uptake mechanism at the apical membrane of Caco-2 cells.

$5 \mathrm{Na}^{+}$-dependent $\mathrm{MPP}^{+}$uptake was sensitive to inhibition by the organic cations; decynium-22 $(2 \mu \mathrm{M})$, TEA $(2 \mathrm{mM})$ and cimetidine $(5 \mathrm{mM})$ but not by carnitine, guanidine or proline.

6 These results suggest that net secretion of $\mathrm{MPP}^{+}$across the apical membrane of Caco-2 cells is a function of the relative contributions of $\mathrm{MPP}^{+}$secretion mediated by $\mathrm{P}$-glycoprotein and $\mathrm{MPP}^{+}$ absorption mediated by a novel $\mathrm{Na}^{+}$-dependent transport mechanism.

British Journal of Pharmacology (2000) 129, 619-625

Keywords: Caco-2 cells; organic cation transport; $\mathrm{MPP}^{+}$; P-glycoprotein

Abbreviations: bp, base pair; DMEM, Dulbecco's modified Eagle's medium; HEPES, 4-(2-hydroxyethyl)-1-piperazineethanesulphonic acid; MPP, 1-methyl-4-phenylpyridinium; NMDG, N-methyl-D-glucamine; OCT, organic cation transporter; PCR, polymerase chain reaction; TEA, tetraethylammonium; Tris, 2-amino-2-hydroxymethyl-1,3propanediol

\section{Introduction}

The secretion of xenobiotics and endogenous metabolites is a primary physiological function of the intestine (Israili \& Dayton, 1984). In concert with xenobiotic metabolism and elimination by the liver and kidney, the intestine provides an important route for drug clearance and an important means to modulate drug absorption across the gastrointestinal tract. Intestinal clearance of cationic drug molecules involves the uptake of organic cations across the basolateral membrane into the cell driven by an inside negative membrane potential, followed by exit from the cell across the apical membrane. At least two transport mechanisms are important in the secretion of organic cations across the apical membrane of enterocytes: P-glycoprotein and organic cation proton antiport. Pglycoprotein mediates the active secretion of a wide range of lipophilic drug molecules across the apical membrane (Hunter et al., 1993; Hsing, et al., 1992; Saitoh et al., 1995; Thiebaut et al., 1987). Organic cation/proton antiport, in which organic cations efflux across the apical membrane in exchange for protons, is important in the intestinal elimination of less hydrophobic organic cations that are not substrates for Pglycoprotein (Turnheim \& Lauterbach, 1977; Miyamoto et al. 1988). In addition to P-glycoprotein and organic cation proton antiport, there is also substantial evidence for the uptake of

*Author for correspondence. organic cations across the apical membrane. Apical uptake of organic cations is an important mechanism for the absorption of a number of important organic cations from the lumen of the gut and as a mechanism to modulate drug secretion (Kuo et al., 1994; Tamai et al., 1997).

In the kidney, in addition to P-glycoprotein (Horio et al., 1989; Simmons et al., 1997), a number of transport proteins involved in the transport of a range of organic cations have recently been cloned. For a prototypic organic cation such as the potent neurotoxin; 1-methyl-4-phenylpyridinium $\left(\mathrm{MPP}^{+}\right)$, the potential sensitive transport mechanism involved in its accumulation across the basolateral membrane (Ullrich et al., 1992) has been identified, at the molecular level, as OCT1 (Grundemann et al., 1994). At the apical membrane, extrusion of $\mathrm{MPP}^{+}$from the cell is mediated by organic cation/proton antiport (David et al., 1995). Recently Grundemann and colleagues (1999) provided evidence that $\mathrm{MPP}^{+} /$proton antiport was the result of the expression of the organic cation transporter OCT2 in the apical membrane of rat proximal tubule. The expression of both OCT1 and OCT2 has been demonstrated in human intestinal Caco-2 cells (O'Neill et al., 1999), a cell line often used as a model of small intestinal function. This raises the possibility that intestinal expression of OCT1 and OCT2 may play an important role in the intestinal handling of organic cations like $\mathrm{MPP}^{+}$. 


\section{Methods}

\section{Materials}

Cell culture media, supplements, and tissue culture plastics were supplied by Life Technologies (Paisley, U.K.). Tissue culture filters (Transwells) were from Costar (High Wycombe, U.K.). $\left[{ }^{3} \mathrm{H}\right]-\mathrm{MPP}$ and $\left[{ }^{14} \mathrm{C}\right]-\mathrm{mannitol}$ were purchased from NEN. All other chemicals and biochemicals were obtained from Sigma (Poole, U.K.) or BDH (Lutterworth, U.K.) and were of the highest quality available.

\section{Reverse transcription $(R T)$ polymerase-chain reaction (PCR)}

Poly-A ${ }^{+}$RNA extracted from Caco-2 cells (21 days after confluency was reached, passage 102) was reverse transcribed (MMLV reverse transcriptase, Helena Biosciences U.K.) and the resulting cDNA subjected to PCR analysis using the Expand Long Template PCR System (Boehringer-Mannheim, Germany) according to the manufacturer's instructions, using an annealing temperature of $56^{\circ} \mathrm{C}$. For amplification of hOCT1 the primers used were 5'-CAT GAG CAT GCT GAG CCA T-3' (positions 53-71) and 5'-GGG TAG GCA AGT ATG AGG-3' (positions 1828-1845) and for hOCT2 5'-GCC CTC CTG CCT GCA GGA T-3' (positions 125-143) and 5'TAG ATG CTC CTC TCC ACC-3' (positions 2188-2206). Negative controls, excluding cDNA from the reaction, were carried out in all cases. The resulting products were isolated from the agarose gel, and subjected to automated sequencing (ABI PRISM 377 DNA sequencer).

\section{Cell culture}

Caco-2 cells (passage 100-109) were grown in Dulbecco's modified Eagle's medium (DMEM) (with $4.5 \mathrm{~g}^{-1}$ glucose) supplemented with $10 \%\left(\mathrm{v} \mathrm{v}^{-1}\right)$ foetal calf serum (FCS), $2 \mathrm{mmol} \mathrm{l}^{-1}$ glutamine, $1 \%$ non-essential amino acids and gentamycin $\left(60 \mu \mathrm{g} \mathrm{ml}^{-1}\right)$. Cells were maintained in culture at $37^{\circ} \mathrm{C}$ in a $5 \% \quad \mathrm{CO}_{2}, 95 \%$ air atmosphere, with the culture media replaced every 2 days. For transport studies, cell monolayers were prepared by seeding at high density $\left(9.0 \times 10^{5}\right.$ cells $\left.\mathrm{cm}^{-2}\right)$ onto $12 \mathrm{~mm}$ diameter Transwell polycarbonate filter supports (Costar). Monolayer confluence was estimated by microscopy and measurement of transepithelial electrical resistance $\left(\mathrm{R}_{\mathrm{T}}\right)$. Experiments were performed 14-21 days after confluence was achieved and $18-24 \mathrm{~h}$ after feeding.

\section{Transport measurements}

Bidirectional transepithelial flux measurements were performed essentially as previously described by Simmons (1990). Briefly, the cell monolayers (grown on $12.5 \mathrm{~mm}$ diameter filters) were extensively washed four times in $500 \mathrm{ml}$ of modified Krebs' buffer (mmol $1^{-1}$ ): $\mathrm{NaCl}, 140 ; \mathrm{KCl}, 5.4$; $\mathrm{MgSO}_{4}, 1.2 ; \mathrm{KH}_{2} \mathrm{PO}_{4}, 0.3 ; \mathrm{NaH}_{2} \mathrm{PO}_{4}, 0.3 ; \mathrm{CaCl}_{2}, 2 ;$ Glucose, 5; HEPES, $10, \mathrm{Na}^{+}$-free Krebs' buffer (composition as above, except that either N-methyl-D-glucamine (NMDG) $\mathrm{Cl}^{-}$or choline $\mathrm{Cl}^{-}$replaced $\mathrm{NaCl}$ and $\mathrm{KH}_{2} \mathrm{PO}_{4}$ replaced $\mathrm{NaH}_{2} \mathrm{PO}_{4}$ ) or $\mathrm{Cl}^{-}$free Krebs' buffer (composition as above, except that $\mathrm{Cl}^{-}$salts were replaced with gluconate salts). All solutions were buffered to the desired $\mathrm{pH}$ at $37^{\circ} \mathrm{C}$, with Tris base. The filters were then placed in 12-well plastic plates, each well containing $1 \mathrm{ml}$ of prewarmed unlabelled substrate $\left(\mathrm{MPP}^{+}\right.$or vinblastine) and mannitol with a further $0.5 \mathrm{ml}$ added to the upper chamber (apical solution) and preincubated for $1 \mathrm{~h}$. Apical to basolateral flux and basolateral to apical flux of either $\mathrm{MPP}^{+}$or vinblastine were measured in resistance paired monolayers. To begin the flux, $\left[{ }^{3} \mathrm{H}\right]-\mathrm{MPP}^{+}\left(0.5 \mu \mathrm{Ci} \mathrm{ml}^{-1}\right)$ or $\left[{ }^{3} \mathrm{H}\right]$-vinblastine $\left(0.5 \mu \mathrm{Ci} \mathrm{ml}{ }^{-1}\right)$ and $\left[{ }^{14} \mathrm{C}\right]$-mannitol $(0.25 \mu \mathrm{Ci}$ $\mathrm{ml}^{-1}$ ) were added to either the apical or basolateral chamber. $100 \mu \mathrm{l}$ aliquots were removed from the appropriate chamber at $60 \mathrm{~min}$ intervals and the volume replaced with unlabelled Krebs' buffer. ${ }^{3} \mathrm{H}$ or ${ }^{14} \mathrm{C}$ activity in the samples was determined by liquid scintillation spectrometry using a Beckman LS 5000CE liquid scintillation counter. Fluxes across the monolayers into the contralateral chamber are expressed as $\mathrm{nmol} \mathrm{cm}{ }^{-2} \mathrm{~h}^{-1}$ and are corrected for flux via the paracellular route. Initial rates of $\mathrm{MPP}^{+}$uptake across the apical membrane of Caco-2 cell monolayers was measured in an almost identical manner except that the cells were preincubated in Krebs' buffer not unlabelled substrate. Uptake was initiated by the replacement of the Krebs' buffer in the apical chamber with Krebs' buffer containing $\left[{ }^{3} \mathrm{H}\right]-\mathrm{MPP}^{+}$ $\left(0.5 \mu \mathrm{Ci} \mathrm{ml}{ }^{-1}\right)$ and $\left[{ }^{14} \mathrm{C}\right]$-mannitol $\left(0.25 \mu \mathrm{Ci} \mathrm{ml}^{-1}\right)$. At the end of the incubation period, cell monolayers were washed four times in $500 \mathrm{ml}$ volumes of ice-cold Krebs' buffer (or $\mathrm{Na}^{+}$-free or $\mathrm{Cl}^{-}$-free Krebs' buffer) at $\mathrm{pH} 7.4$ to remove extracellular isotope. The cell monolayers were then excised from the filter insert and the cell associated isotope determined by liquid scintillation counting. Initial rates of uptake are expressed as pmoles $\mathrm{cm}^{-2} \mathrm{~min}^{-1}$.

\section{Statistical analysis}

Data are expressed as mean \pm s.e.mean. Statistical comparison of mean values was made using a Student's $t$-test (2-tailed solution) for paired or unpaired data as appropriate. For multiple comparisons, a one-way analysis of variance (ANOVA) test was employed and significance assigned using a Dunnett post-test.

\section{Results}

hOCT1 and hOCT2 are expressed in Caco-2 cell monolayers

The expression of hOCT1 and hOCT2 in polarized monolayers of Caco- 2 cells was assayed by RT - PCR. Figure 1a shows the (a)

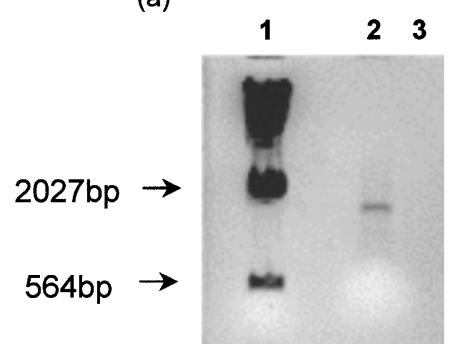

(b)

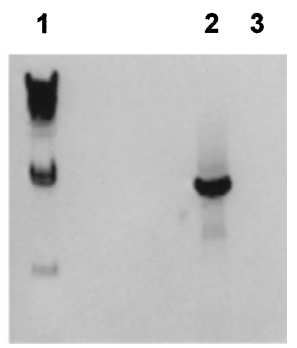

Figure 1 Expression of hOCT1 and hOCT2 mRNA in Caco-2 cells was identified by RT-PCR. (a) $0.8 \%$ agarose gel, Lane 1 ; $\lambda$ HindIII DNA marker. Lane 2; 1792 bp RT - PCR product from Caco-2 cells, using primers specific to hOCT1. Product is consistent with expected size of hOCT1. Lane 3; Negative PCR control. (b) $0.8 \%$ agarose gel, Lane 1; $\lambda$ HindIII DNA marker. Lane 2; 2081 bp RT-PCR product from Caco-2 cells, using primers specific to hOCT2. Product is consistent with expected size of hOCT2. Lane 3; Negative PCR control. 
1792 bp product isolated using primers specific to hOCT1 and Figure $1 \mathrm{~b}$ shows the $2081 \mathrm{bp}$ product isolated using primers specific to hOCT2. When sequenced these products were found to be $100 \%$ identical at the nucleotide level to the published sequences of hOCT1 and hOCT2 respectively (Gorboulev et al., 1997). Thus, similar to native intestine (Gorboulev et al., 1997), both hOCT1 and hOCT2 appear to be expressed in polarized monolayers of Caco-2 cells.

\section{Transepithelial fluxes of $\mathrm{MPP}^{+}$across Caco-2 monolayers}

The bi-directional transepithelial fluxes of $25 \mu \mathrm{M} \mathrm{MPP}{ }^{+}$across monolayers of Caco-2 cells showed a marked asymmetry (Figure 2). Basolateral to apical flux of $\mathrm{MPP}^{+}$was significantly greater than the corresponding apical to basolateral flux, resulting in a significant net secretory flux of $\mathrm{MPP}^{+}$from the basolateral to apical chamber $\left(0.87 \pm 0.05 \mathrm{nmol} \mathrm{cm}^{-2} \mathrm{~h}^{-1}\right.$, $P<0.01, n=6)$. In order to test the involvement of OCT1 or OCT2 in this process, we measured the net flux of $25 \mu \mathrm{M}$ $\mathrm{MPP}^{+}$in the presence of the potent inhibitor of OCTmediated transport, decynium-22 or the competitive substrate TEA. Apical addition of $2 \mu \mathrm{M}$ decynium-22 (Figure 3a), had no significant effect upon the magnitude of either the apical to basolateral $\left(0.9 \pm 0.15 \mathrm{nmol} \mathrm{cm}{ }^{-2} \mathrm{~h}^{-1}\right.$ vs $0.77 \pm 0.1 \mathrm{nmol}$ $\left.\mathrm{cm}^{-2} \mathrm{~h}^{-1}, P>0.5, n=6\right)$ or the basolateral to apical flux of $\mathrm{MPP}^{+}\left(2.05 \pm 0.08 \mathrm{nmol} \mathrm{cm}{ }^{-2} \mathrm{~h}^{-1}\right.$ vs $2.25 \pm 0.1 \mathrm{nmol} \mathrm{cm}^{-2}$ $\left.\mathrm{h}^{-1}, P>0.5, \bar{n}=6\right)$. Equally, addition of $2 \mu \mathrm{M}$ decynium- 22 to the basolateral membrane had no significant effect upon $\mathrm{MPP}^{+}$flux in either the apical to basolateral $\left(0.75 \pm 0.1 \mathrm{nmol} \mathrm{cm} \mathrm{cm}^{-2} \mathrm{~h}^{-1}, P>0.5, n=6\right)$ or basolateral to apical $\left(2.08 \pm 0.1 \mathrm{nmol} \mathrm{cm}{ }^{-2} \mathrm{~h}^{-1}, P>0.5, n=6\right)$ direction. Similarly, $2 \mathrm{mM}$ TEA had no effect upon the magnitude of $\mathrm{MPP}^{+}$secretion when added to either the basolateral or apical bathing solution (Figure $3 b$ ).

\section{The effects of inhibitors of P-glycoprotein on transepithelial fluxes of $M P P^{+}$}

In the next series of experiments, we investigated the effects of cyclosporin A and verapamil, both well characterized competitive substrates of P-glycoprotein, on the transepithelial fluxes of $\left[{ }^{3} \mathrm{H}\right]-\mathrm{MPP}^{+}$across Caco- 2 cell monolayers. Figure $4 \mathrm{a}$ shows that addition of $100 \mu \mathrm{M}$ cyclosporin $\mathrm{A}$ to the apical membrane of Caco-2 cell monolayers abolished the net

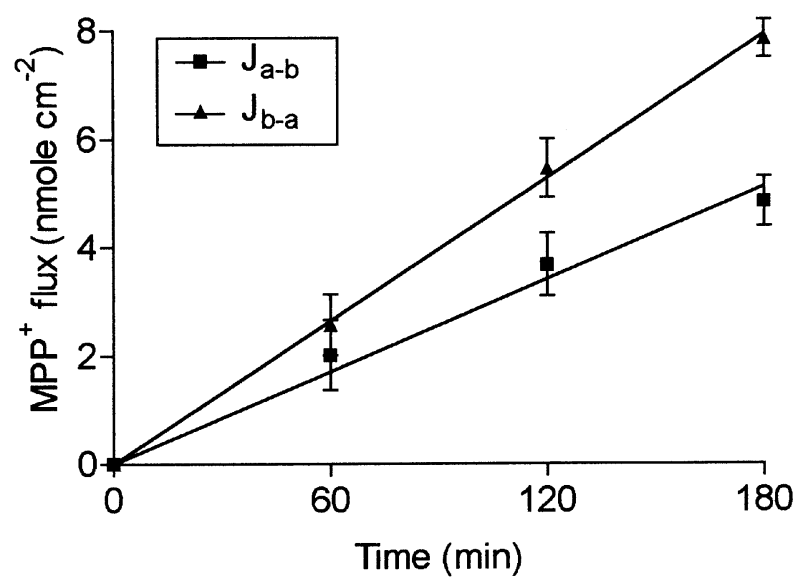

Figure 2 Transport of $\mathrm{MPP}^{+}$across Caco-2 cell monolayers. Apical to basolateral $\left(\mathbf{J}_{\mathrm{a}-\mathrm{b}}\right)$ and basolateral to apical fluxes $\left(\mathrm{J}_{\mathrm{b}-\mathrm{a}}\right)$ of $\left[{ }^{3} \mathrm{H}\right]$ MPP $(25 \mu \mathrm{M})$ were determined over a $3 \mathrm{~h}$ period. The results are expressed as the mean \pm s.e.mean of six separate determinations. secretion of $\mathrm{MPP}^{+}$. Indeed, cyclosporin A reversed the direction of $\mathrm{MPP}^{+}$transport from net secretion $\left(0.7 \pm 0.1 \mathrm{nmol} \mathrm{cm} \mathrm{cm}^{-2} \mathrm{~h}^{-1}, n=6\right)$ to a net absorption of $\mathrm{MPP}^{+}$ $\left(0.68 \pm 0.1 \mathrm{nmol} \mathrm{cm}{ }^{-2} \mathrm{~h}^{-1}, P<0.001, n=6\right)$. Cyclosporin A significantly inhibited the basolateral to apical flux of $\mathrm{MPP}^{+}$ $(P<0.001)$. This was mirrored by an almost identical increase in apical to basolateral flux of $\mathrm{MPP}^{+}(P<0.001)$ (Figure 4a). Taken together these results suggest that the magnitude and direction of $\mathrm{MPP}^{+}$flux across the apical membrane is a balance between $\mathrm{MPP}^{+}$uptake across the apical membrane, mediated by a cyclosporin A insensitive transporter, and $\mathrm{MPP}^{+}$efflux mediated by P-glycoprotein. A similar inhibition of basolateral to apical $\mathrm{MPP}^{+}$flux was found with the apical addition of verapamil $(100 \mu \mathrm{M})$. However, in contrast to the actions of cyclosporin A, verapamil also inhibited apical to basolateral $\mathrm{MPP}^{+}$flux (Figure 4b). Inhibition of $\mathrm{MPP}^{+}$ uptake across the apical membrane probably reflects competition between verapamil and $\mathrm{MPP}^{+}$for a common uptake pathway.
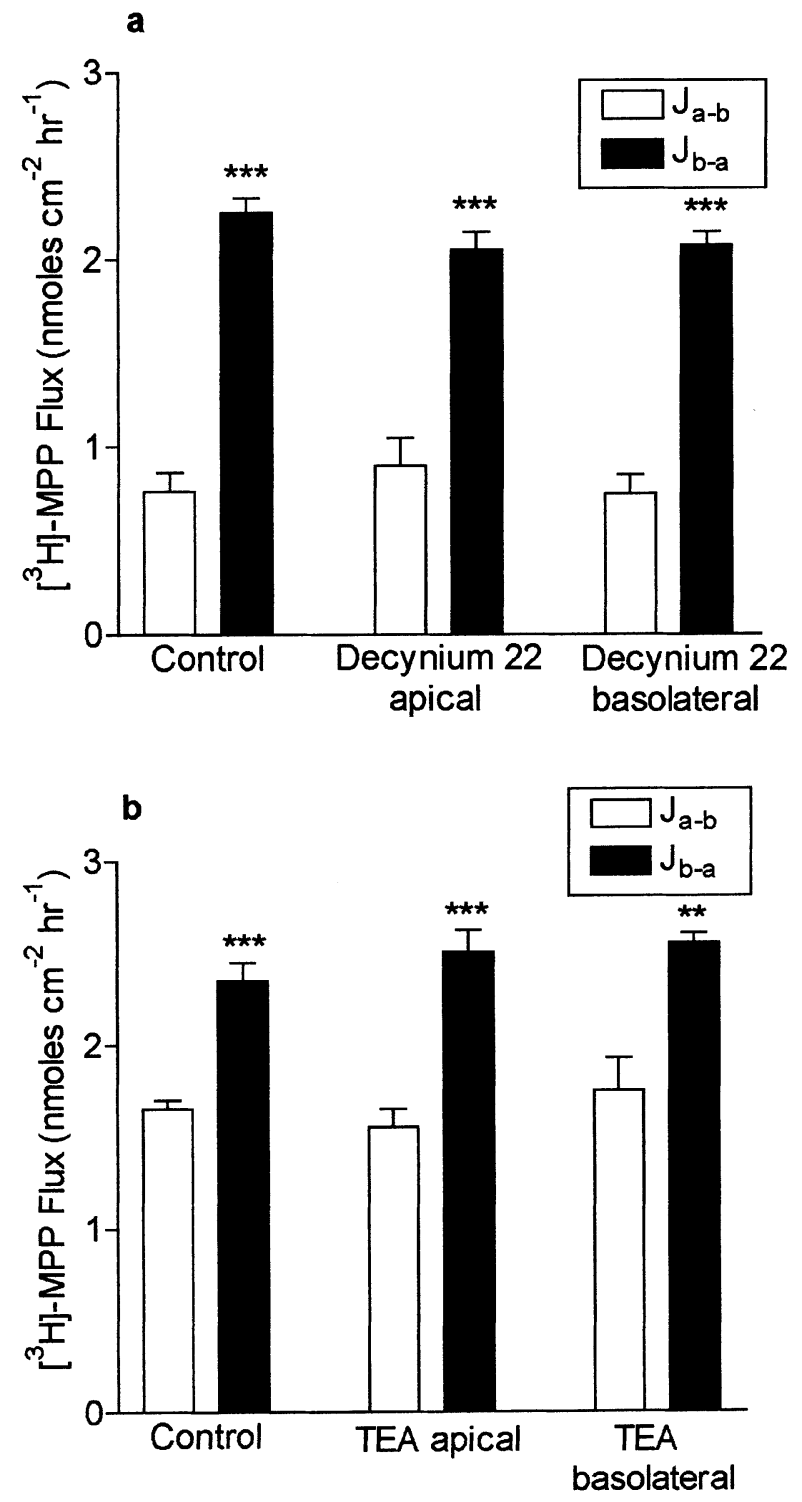

Figure 3 The effect of (a) decynium $22(2 \mu \mathrm{M})$ and (b) TEA (2 mM) upon transepithelial fluxes of $\left[{ }^{3} \mathrm{H}\right]-\mathrm{MPP}^{+}(25 \mu \mathrm{M})$ across epithelial monolayers of Caco-2 cells. Apical to basolateral flux $\left(\mathrm{J}_{\mathrm{a}-\mathrm{b}}\right)$ and basolateral to apical $\left(\mathrm{J}_{\mathrm{b}-\mathrm{a}}\right)$ were measured over a $2 \mathrm{~h}$ period. The results are the mean \pm s.e.mean of six separate determinations. $* * * P<0.001, * * P<0.01$ compared to $\left(\mathrm{J}_{\mathrm{a}-\mathrm{b}}\right)$ in each data set. 
a

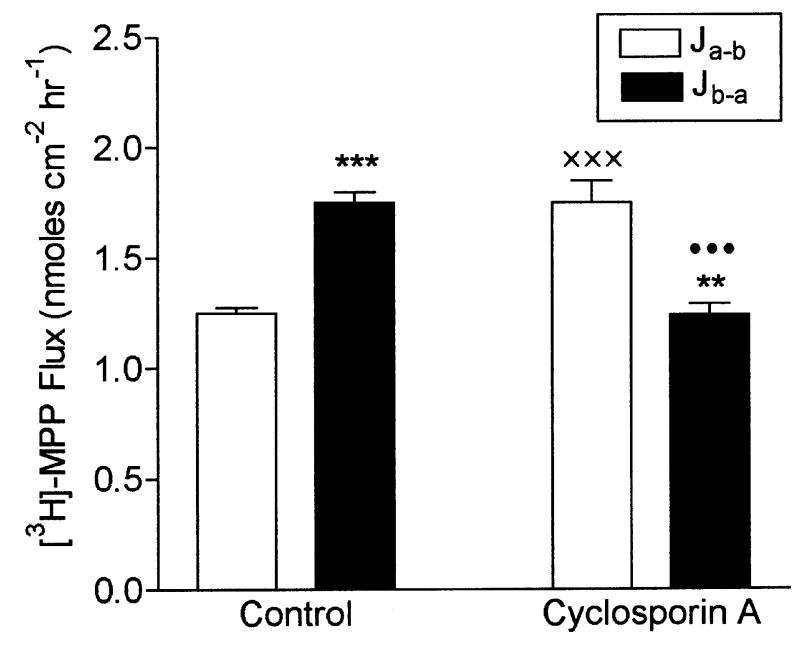

b

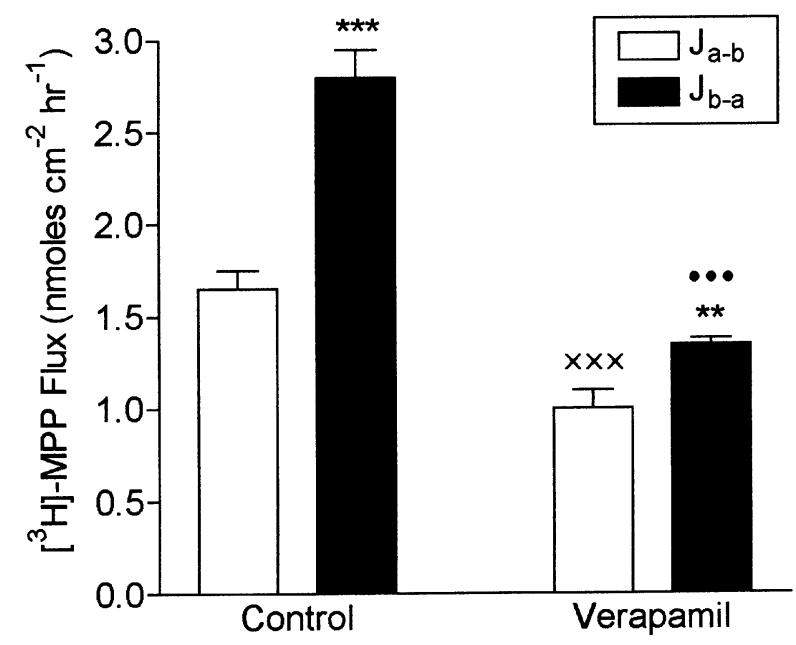

Figure 4 The effect of apical addition of (a) cyclosporin $(10 \mu \mathrm{M})$ and (b) verapamil $(100 \mu \mathrm{M})$ upon transepithelial fluxes of $\left[{ }^{3} \mathrm{H}\right]-\mathrm{MPP}^{+}$ $(25 \mu \mathrm{M})$ across epithelial monolayers of Caco-2 cells. Apical to basolateral flux $\left(\mathrm{J}_{\mathrm{a}-\mathrm{b}}\right)$ and basolateral to apical $\left(\mathbf{J}_{\mathrm{b}-\mathrm{a}}\right)$ were measured over a $2 \mathrm{~h}$ period. The results are the mean \pm s.e.mean of six separate determinations. ${ }^{* * *} P<0.001,{ }^{* *} P<0.01$ compared to $\left(\mathrm{J}_{\mathrm{a}-\mathrm{b}}\right)$ in each data set; $\mathrm{xxx} P<0.001$ compared to $\left(\mathrm{J}_{\mathrm{a}-\mathrm{b}}\right)$ under control conditions; ••• $P<0.001$ compared to $\left(\mathrm{J}_{\mathrm{b}-\mathrm{a}}\right)$ under control conditions in both (a) and (b).

Transepithelial fluxes of vinblastine across Caco-2 cell monolayers

Vinblastine, a prototypic P-glycoprotein substrate has previously been used to demonstrate the expression of $\mathrm{P}$ glycoprotein in the apical membrane of Caco-2 cells. To demonstrate the importance of P-glycoprotein in the secretion of $\mathrm{MPP}^{+}$across the apical membrane of Caco-2 cells, we measured the ability of $\mathrm{MPP}^{+}$to inhibit vinblastine secretion. Figure 5 shows that in the absence of $\mathrm{MPP}^{+}$, the basolateral to apical flux of $\left[{ }^{3} \mathrm{H}\right]$-vinblastine was found to be significantly greater than the apical to basolateral flux $(133 \mathrm{pmol}$ $\mathrm{cm}^{-2} \mathrm{~h}^{-1} \quad$ vs $\left.19.6 \pm 3.2 \mathrm{pmol} \mathrm{cm}{ }^{-2} \mathrm{~h}^{-1}, \quad P<0.001, \quad n=12\right)$ consistent with a net secretion of vinblastine across the cell monolayer. Addition of $100 \mu \mathrm{M} \mathrm{MPP}{ }^{+}$to the apical membrane of Caco-2 cells resulted in a significant decrease in the basolateral to apical flux of vinblastine $(P<0.001$, $n=12$ ) consistent with an interaction between vinblastine and

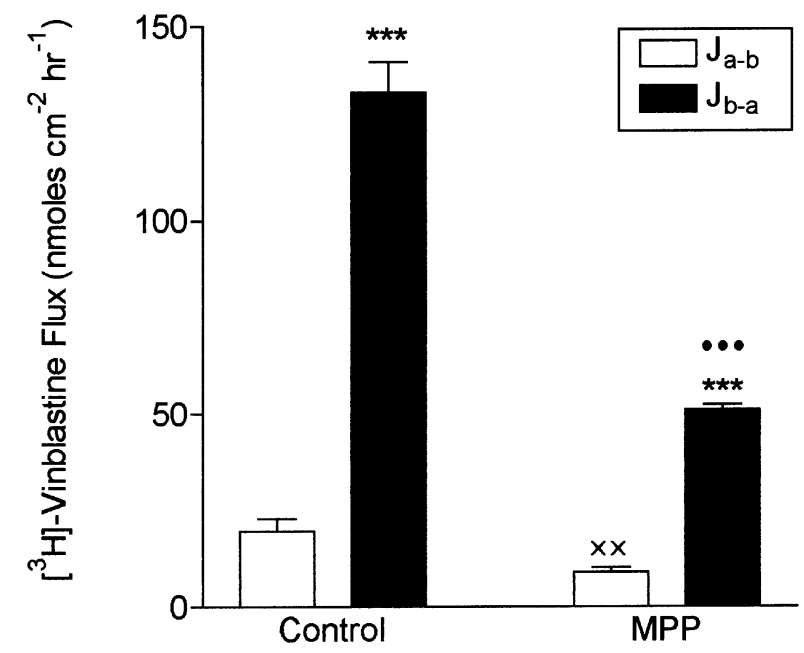

Figure 5 The effect of apical addition of $\mathrm{MPP}^{+}(100 \mu \mathrm{M})$ upon transepithelial flux of $\left[{ }^{3} \mathrm{H}\right]$-vinblastine $(1 \mu \mathrm{M})$ across epithelial monolayers of Caco-2 cells. Apical to basolateral flux $\left(\mathrm{J}_{\mathrm{a}-\mathrm{b}}\right)$ and basolateral to apical flux $\left(\mathrm{J}_{\mathrm{b}-\mathrm{a}}\right)$ were measured over a $2 \mathrm{~h}$ period. The results are the mean \pm s.e.mean of six separate determinations. *** $P<0.001$ compared to $\left(\mathrm{J}_{\mathrm{a}-\mathrm{b}}\right)$ in each data set; $\mathrm{xx} P<0.01$ compared to $\left(\mathrm{J}_{\mathrm{a}-\mathrm{b}}\right)$ under control conditions; $\bullet \bullet P<0.001$ compared to $\left(\mathrm{J}_{\mathrm{b}-\mathrm{a}}\right)$ under control conditions.

$\mathrm{MPP}^{+}$for P-glycoprotein. Similar to the action of verapamil upon $\mathrm{MPP}^{+}$flux (Figure 4b), $\mathrm{MPP}^{+}$also caused a significant decrease in the apical to basolateral flux of vinblastine $(P<0.01, n=12)$.

\section{$\mathrm{Na}^{+}$-dependent uptake of $\mathrm{MPP}^{+}$across the apical membrane of Caco-2 cell monolayers}

The flux data presented above suggest that both uptake and efflux of $\mathrm{MPP}^{+}$occur at the apical membrane of Caco- 2 cells We have provided clear evidence that the efflux of $\mathrm{MPP}^{+}$is mediated by the action of P-glycoprotein. To identify and characterize the transport mechanism responsible for $\mathrm{MPP}^{+}$ uptake, we measured the initial linear uptake rate of $\mathrm{MPP}^{+}$ across the apical membrane of epithelial monolayers of Caco2 cells grown on permeable filter supports. $\mathrm{MPP}^{+}$uptake across the apical membrane of Caco-2 was highly $\mathrm{Na}^{+}$dependent. Replacing $\mathrm{NaCl}$ in the uptake buffer with choline $\mathrm{Cl}^{-}$(Figure 6a) significantly reduced the rate of uptake of $25 \mu \mathrm{M} \mathrm{MPP}^{+}\left(8.9 \pm 0.3 \mathrm{pmol} \mathrm{cm}{ }^{-2} \mathrm{~min}^{-1}\right.$ vs $1.1 \pm 0.1 \mathrm{pmol}$ $\left.\mathrm{cm}^{-2} \mathrm{~min}^{-1}, P<0.001, n=6\right)$. A similar reduction in $\mathrm{MPP}^{+}$ uptake was found if $\mathrm{NaCl}$ was replaced by NMDG $\mathrm{Cl}$ (data not shown). In contrast to the marked effect of $\mathrm{Na}^{+}$removal upon $\mathrm{MPP}^{+}$uptake at the apical membrane, replacement of $\mathrm{Cl}^{-}$ions in the uptake media by the less permeant gluconate anion resulted in only a modest $(\sim 25 \%)$ reduction in $\mathrm{MPP}^{+}$ uptake (Figure 6b. $9.1 \pm 0.3$ vs $6.9 \pm 0.2 \mathrm{pmol} \mathrm{cm}^{-2} \mathrm{~min}^{-1}$, $P<0.001, n=6)$.

\section{$\mathrm{MPP}^{+}$uptake across the apical membrane of Caco-2} cell monolayers is $\mathrm{pH}$-dependent

The uptake of $\mathrm{MPP}^{+}$across the apical membrane of Caco-2 cells also showed modest $\mathrm{pH}$ dependence. Acidification of the extracellular medium from $\mathrm{pH} 7.4$ to $\mathrm{pH} 6.5$ significantly reduced the uptake of $\mathrm{MPP}^{+}\left(9.4 \pm 0.1\right.$ vs $7.1 \pm 0.1 \mathrm{pmol} \mathrm{cm}^{-2}$ $\min ^{-1}, P<0.001, n=6$ ). In contrast, raising the $\mathrm{pH}$ of the extracellular buffer from $\mathrm{pH} 7.4$ to $\mathrm{pH} 8.4$ had no significant effect upon the magnitude of $\mathrm{MPP}^{+}$uptake across the apical membrane. 
a

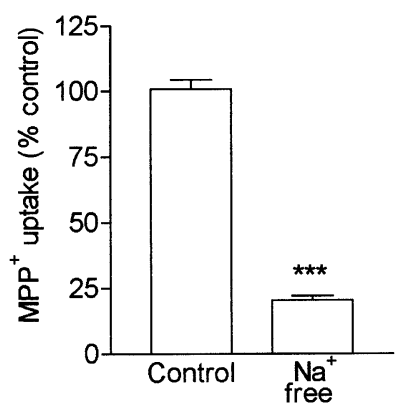

Figure 6 Initial rates of $\left[{ }^{3} \mathrm{H}\right]-\mathrm{MPP}^{+}(25 \mu \mathrm{M})$ uptake across the apical membrane of epithelial monolayers of Caco-2 cells grown on permeable filter supports. $\mathrm{MPP}^{+}$uptake was measured over a $10 \mathrm{~m}$ uptake period (a) in normal Krebs' buffer (control condition) and in $\mathrm{Na}^{+}$-free Krebs' buffer and (b) in normal Krebs' buffer (control condition) and in $\mathrm{Cl}^{-}$-free Krebs' buffer. Uptake is expressed as \% of the control condition. The results are the mean \pm s.e.mean of six separate determinations. ${ }^{* * *} P<0.001$ compared to control condition in both (a) and (b).
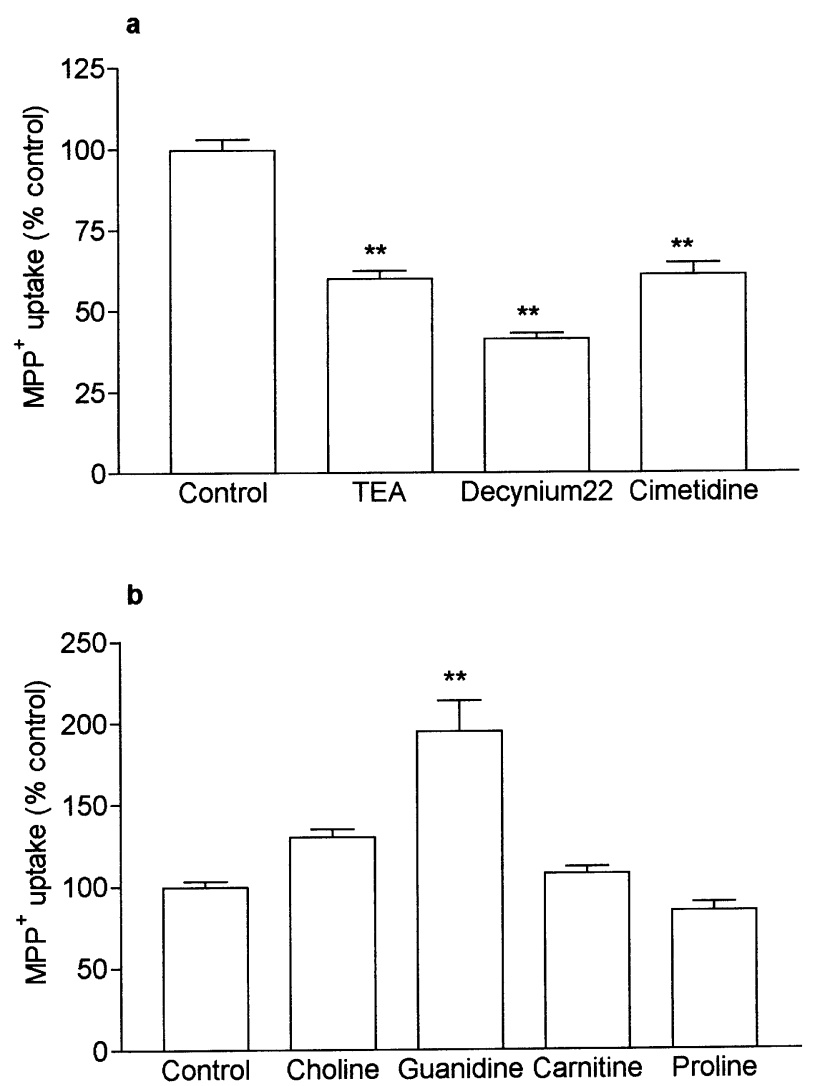

Figure 7 Effects of various compounds on the uptake of $\left[{ }^{3} \mathrm{H}\right]-\mathrm{MPP}^{+}$ $(25 \mu \mathrm{M})$ across the apical membrane of epithelial monolayers of Caco-2 cells grown on permeable filter supports. The uptake of $\mathrm{MPP}^{+}$was measured in the presence of (a) 2 mM TEA; $2 \mu \mathrm{M}$ decynium 22 or $5 \mathrm{~mm}$ cimetidine and (b) $5 \mathrm{~mm}$ choline; guanidine; carnitine or proline. Uptake is expressed as \% of the control condition. The results are the mean \pm s.e.mean of six separate determinations. ${ }^{* *} P<0.01$ compared to control condition in both (a) and (b).

\section{Substrate selectivity of $M P P^{+}$uptake across the apical membrane of Caco-2 cell monolayers}

The substrate selectivity of apical $\mathrm{MPP}^{+}$uptake was assessed by measuring the ability of a range of organic cations to cisinhibit $\left[{ }^{3} \mathrm{H}\right]-\mathrm{MPP}^{+}$uptake. As shown in Figure $7 \mathrm{a}$, the uptake of $\mathrm{MPP}^{+}$across the apical membrane of Caco- 2 cells was significantly reduced in the presence of $2 \mathrm{mM}$ TEA, $2 \mu \mathrm{M}$ decynium-22 and $5 \mathrm{~mm}$ cimetidine $(P<0.01, n=6$, in all cases). However, $\mathrm{MPP}^{+}$uptake was not sensitive to $5 \mathrm{mM}$ choline, carnitine or proline (Figure $7 \mathrm{~b}$ ). Interestingly, $\mathrm{MPP}^{+}$uptake was significantly stimulated in the presence of $5 \mathrm{~mm}$ guanidine $(P<0.01, n=6)$. Initially we thought that this might result from a rapid uptake of guanidine into the cell followed by a trans-stimulation of $\mathrm{MPP}^{+}$uptake, however we could not mimic the effect of guanidine upon $\mathrm{MPP}^{+}$uptake by preloading the cells with guanidine before measuring $\mathrm{MPP}^{+}$ uptake (data not shown). It therefore remains unclear as to the mechanism by which guanidine addition stimulates $\mathrm{MPP}^{+}$ uptake.

\section{Discussion}

The present study reports the characterization of $\mathrm{MPP}^{+}$ transport across epithelial monolayers of human intestinal Caco-2 cells. $\mathrm{MPP}^{+}$is a prototypic substrate for a number of cloned organic cation transporters including OCT1 (Grundemann et al., 1994); OCT2 (Okuda et al., 1996); OCT3/EMT (Kekuda et al., 1998; Grundemann et al., 1999) and OCTN2 (Tamai et al. 1998: Wu et al., 1998). Common features of these transporters include inhibition by decynium-22 and competition between $\mathrm{MPP}^{+}$and TEA (Grundemann et al., 1999).

The results of this study show clear differences in the handling of $\mathrm{MPP}^{+}$by Caco- 2 cell monolayers compared with its handling in the kidney. For example, the current model for the renal secretion of organic cations like $\mathrm{MPP}^{+}$supports a central role for OCT1 in organic cation uptake across the basolateral membrane (Ullrich et al., 1992; Grundemann et al., 1994). In Caco-2 cells, although we can clearly demonstrate the expression of OCT1 in Caco-2 cells (Figure 1a), basolateral to apical flux of $\mathrm{MPP}^{+}$was not inhibited by either decynium-22 or TEA. These results argue against OCT1 playing a significant role in the uptake of $\mathrm{MPP}^{+}$across the basolateral membrane of Caco-2 cells. Since $\mathrm{MPP}^{+}$is a relatively lipophilic molecule, it is possible that in Caco-2 cells, the contribution of passive diffusion of $\mathrm{MPP}^{+}$across the basolateral membrane masks the contribution of OCT1 to the total uptake of $\mathrm{MPP}^{+}$. Passive diffusion is known to be important in the basolateral uptake of P-glycoprotein substrates (Hunter et al., 1993; Cormet-Boyaka et al., 1998). Alternatively, uptake of $\mathrm{MPP}^{+}$across the basolateral membrane of Caco- 2 cells may be mediated by a mechanism distinct from OCT1 or OCT2. Recently, the uptake of cimetidine and ranitidine across the basolateral membrane of Caco-2 cell monolayers was found to be TEA-insensitive. Based on the hydrophilic nature of these drugs, the authors postulated the involvement of a novel TEA-insensitive organic cation transporter (Collet et al., 1999).

Organic cation/proton antiport is thought be the major mechanism involved in the renal and hepatic extrusion of $\mathrm{MPP}^{+}$across the apical and canalicular membranes respectively (David et al., 1995; Moseley et al., 1997). Organic cation/ proton antiport activity has also been found in the small intestine with the demonstration, in brush border membrane vesicles, of guanidine/proton antiport (Miyamoto et al., 1988) and more recently cimetidine/proton antiport (Piyapolrungroj et al., 1999). Furthermore, organic cation/proton antiport has been implicated in the secretion of cimetidine across epithelial monolayers of Caco-2 cells (Pade \& Stavchansky, 1997). However, the pharmacological profile of $\mathrm{MPP}^{+}$efflux across the apical membrane of Caco-2 cell monolayers suggests that 
P-glycoprotein rather than organic cation/proton antiport is the mechanism responsible for $\mathrm{MPP}^{+}$secretion. Thus, $\mathrm{MPP}^{+}$ exit across the apical membrane of Caco- 2 cells is not reduced by either decynium-22 or TEA, but is abolished in the presence of either cyclosporin A or verapamil, both potent competitive substrates of P-glycoprotein (Tiberghein \& Loor, 1996). In addition, we were able to demonstrate that, not only was $\mathrm{MPP}^{+}$secretion inhibited by P-glycoprotein substrates, but that $\mathrm{MPP}^{+}$itself acted as a competitive substrate of vinblastine flux. These results perhaps illustrate the fundamental difference in the importance of P-glycoprotein in the intestinal and renal handling of identical substrates. Definitive evidence in support of this concept has come from a series of elegant experiments using a 'knockout' mdrla/mdrlb $(-/-)$ - mouse model. Smit et al. (1998) showed that, in the absence of functional Pglycoprotein, intestinal clearance of P-glycoprotein substrates was $80 \%$ less than in normal animals but that, significantly, whole body clearance of these substrates remained at near normal levels. To explain these results it has been proposed that renal clearance of many hydrophobic substrates does not depend upon the functional expression of P-glycoprotein and that increased renal clearance can compensate for the absence of significant intestinal drug clearance.

The inhibition of P-glycoprotein mediated uptake by cyclosporin A unmasked an apical uptake mechanism for $\mathrm{MPP}^{+}$. Thus net secretion of $\mathrm{MPP}^{+}$reflects a balance between secretion via $\mathrm{P}$-glycoprotein and reabsorption. The balance achieved between these two opposing fluxes probably explains in part the variation in asymmetry of $\mathrm{MPP}^{+}$flux observed in different batches of control monolayers. We found that the balance between $\mathrm{MPP}^{+}$secretion and absorption was most affected by variation in the magnitude of apical $\mathrm{MPP}^{+}$uptake (Figures 3 and 4) rather than variation in the magnitude of $\mathrm{MPP}^{+}$secretion. The wide variation in apical $\mathrm{MPP}^{+}$uptake may reflect a regulation of expression of the transporter by endogenous metabolic substrates in the culture media. The uptake of $\mathrm{MPP}^{+}$at the apical membrane showed a marked $\mathrm{Na}^{+}$dependence. This distinguishes it from the majority of organic cation uptake mechanisms so far reported at apical membranes of the small intestine, most of which are $\mathrm{Na}^{+}$independent (Koepsell, 1998). The $\mathrm{Na}^{+}$-dependent uptake of
$\mathrm{MPP}^{+}$was moderately inhibited by both TEA and decynium 22 , and had a $\mathrm{pH}$-profile (inhibited at acid $\mathrm{pH}$ values) which is a feature of the OCT family of transporters (Grundemann et $a l .$, 1999). Of the OCT family of transporters so far identified, only OCTN2 is $\mathrm{Na}^{+}$-dependent. OCTN2 is the $\mathrm{Na}^{+}$dependent carnitine transporter and is found at the apical membrane of intestine (Tamai et al., 1998). However, the uptake of $\mathrm{MPP}^{+}$was not sensitive to cis-inhibition by carnitine, suggesting that $\mathrm{MPP}^{+}$uptake was not mediated by OCTN2. Recently an extraneuronal dopamine transporter has been reported in COS-7 cells which exhibits strong function homology to the neuronal dopamine transporter DAT (Sugamori et al., 1999). The dopamine transporter belongs to a family of $\mathrm{Na}^{+} / \mathrm{Cl}^{-}$dependent transporters and has high affinity for $\mathrm{MPP}^{+}$. However, $\mathrm{MPP}^{+}$uptake into Caco- 2 cells showed only a moderate $\mathrm{Cl}^{-}$dependence $(25 \%)$ as opposed to an $80 \%$ dependence upon $\mathrm{Na}^{+}$, thus ruling out the extraneuronal dopamine transporter as the mechanism responsible for $\mathrm{MPP}^{+}$uptake. Similarly, the lack of inhibition by proline ruled out the involvement of $\mathrm{Na}^{+}$-dependent cationic amino acid transport in $\mathrm{MPP}^{+}$uptake.

In summary, we report the characterization of $\mathrm{MPP}^{+}$ transport across epithelial monolayers of human intestinal Caco-2 cells. The major findings of this study are that Caco-2 cell monolayers secrete $\mathrm{MPP}^{+}$in a basolateral to apical direction. The secretion of $\mathrm{MPP}^{+}$is consistent with passive uptake of $\mathrm{MPP}^{+}$across the basolateral membrane followed by active efflux of $\mathrm{MPP}^{+}$across the apical membrane mediated by P-glycoprotein. Although Caco-2 cells were found to express both hOCT1 and hOCT2, we found no evidence of their role in the secretion of $\mathrm{MPP}^{+}$. In addition we found evidence for a $\mathrm{Na}^{+}$-dependent uptake of $\mathrm{MPP}^{+}$across the apical membrane, which served to modulate the magnitude of P-glycoprotein mediated $\mathrm{MPP}^{+}$secretion. The identity of this transporter remains to be resolved.

This work was supported by the National Kidney Research Fund (R35/1/96). K. Bleasby holds a National Kidney Research Fund Studentship.

\section{References}

COLLETT, A., HigGS, N.B., SIMS, E., ROWLAND, M. \& WARHURST, G. (1999). Modulation of the permeability of $\mathrm{H}_{2}$ receptor antagonists cimetidine and ranitidine by $\mathrm{P}$-glycoprotein in rat intestine and the human colonic cell line Caco-2. J. Pharmacol Exp. Ther., 288, $171-178$.

CORMET-BOYAKA, E., HUNEAU, J., MORDRELLE, A., BOYAKA, P. CARBON, C., RUBINSTEIN, E. \& TOME, D. (1998). Secretion of Sparfloxacin from the human intestinal Caco-2 cell line is altered by P-glycoprotein inhibitors. Antimicrob. Agents Chemother., 42, $2607-2611$.

DAVID,C., RUMRICH, G. \& ULLRICH K. J. (1995). Luminal transport system for $\mathrm{H}^{+} /$organic cations in the rat proximal tubule. Kinetics, dependence on $\mathrm{pH}$; specificity as compared with the contraluminal organic cation transport system. Pfluegers Arch., 430, $477-492$.

GORBOUlEV, V., ULZHEIMER, J.C., AKHOUNDOVA, A., ULZHEIMER-TEUBER, I., KARBACH, U., QUESTER, S., BAUMAN, C., LANG, F., BUSCH, A.E. \& KOEPSELL, H. (1997). Cloning and characterisation of two human polyspecific organic cation transporters. DNA Cell Biol., 16, 871-881.

GRUNDEMANN, D., GORBOULEV, V., GAMBARYAN S., VEHYL, M. \& KOEPSELL, H. (1994). Drug excretion mediated by a new prototype polyspecifc transporter. Nature, 372, 549-552.
GRUNDEMANN, D., LIEBICH, G., KIEFER, N., KOSTER, S. \& SCHOMIG, E. (1999). Selective substrates for non-neuronal monoamine transporters. Mol. Pharmacol., 56, 1-10.

HORIO, M., CHIN, K.V., CURRIER, S.J., GOLDENBERG, S., WILLIAMS, C., PASTAN, I., GOTTESMAN, M.M. \& HANDLER, J. (1989). Transepithelial transport of drugs by the multidrug transporter in cultured Madin-Darby kidney cell epithelia. $J$. Biol. Chem., 264, $14880-14884$.

HSING, S., GATMAITAN, Z. \& ARIAS, I.M. (1992). The function of Gp170, the multidrug-resistance gene product, in the brush border of rat intestinal mucosa. Gastroenterology, 102, 879-885.

HUNTER, J., JEPSON, M.A., TSURUO, T., SIMMONS, N.L. \& HIRST, B.H. (1993). Functional expression of P-glycoprotein in apical membranes of human intestinal Caco-2 cells. J. Biol. Chem., 268, $14991-14997$.

ISRAILI, Z.H. \& DAYTON, P.G. (1984). Enhancement of xenobiotic elimination: role of intestinal excretion. Drug Metab. Rev., 15, $1123-1159$.

KEKUDA, R., PRASAD, P.D., WU, X., WANG, H., FEI, Y-J., LEIBACH, F.H. \& GANAPATHY, V. (1998). Cloning and functional characterisation of a potential-sensitive, polyspecific organic cation transporter (OCT3) most abundantly expressed in placenta. J. Biol. Chem., 273, $15971-15979$. 
KOEPSELL, H. (1998). Organic cation transporters in intestine, kidney, liver and brain. Annu. Rev. Physiol., 60, 243-266.

KUO, S-M., WHITBY, B.R., ARTURSSON, P. \& ZIEMNIAK, J.A. (1994). The contribution of intestinal secretion to the dose dependent absorption of Celiprolol. Pharm. Res., 11, 648-653.

MIYAMOTO, Y., GANAPATHY, V. \& LEIBACH, F.H. (1988). Transport of guanidine in rabbit intestinal brush-border membrane vesicles. Am. J. Physiol., 255, G85-G92.

MOSELEY, R.H., ZUGGER, L.J. \& VAN DYKE, R.J. (1997). The neurotoxin 1-methyl-4-phenylpyridinium is a substrate for the canalicular organic cation $/ \mathrm{H}^{+}$exchanger. J. Pharmacol. Exp. Ther., 281, $34-40$.

OKUDA, M., SAITO, H., URAKAMI, Y., TAKOANO, M. \& INUI, K. (1996). cDNA cloning and functional expression of a novel rat kidney organic cation transporter, OCT2. Biochem. Biophys. Res. Commun., 224, 500-507.

O'NEILL, C.A., STEPHENS, R., ROWLAND, M. \& WARHURST, G. (1999). Molecular expression of polyspecific drug transporters in human intestine. J. Physiol., 517P, 53P.

PADE, V. \& STAVCHANSKY, S. (1997). Estimation of the relative contribution of the transcellular and paracellular pathway to the transport of passively absorbed drugs in the Caco-2 cell culture model. Pharm. Res., 14, 1210-1215.

PIYAPOLRUNGROJ, N., LI, C., PISONI, R.L. \& FLEISHER, D. (1999). Cimetidine transport in brush border membrane vesicles from rat small intestine. J. Pharmacol. Exp. Ther., 289, 346-353.

SAITOH, H. \& AUNGST, B.J. (1995). Possible involvement of multiple P-glycoprotein mediated efflux systems in the transport of verapamil and other organic cations across rat intestine. Pharm. Res., 12, $1304-1310$.

SIMMONS, N.L. (1990). Tissue culture of established cell lines. Methods Enzymol., 191, 426-436.

SIMMONS, N.L., HUNTER, J. \& JEPSON, M.A. (1997). Renal secretion of xenobiotics mediated by P-glycoprotein: Importance to renal function in health and exploitation for targetted drug delivery to epithelial cysts in polycystic kidney disease. Adv. Drug Deliv. Rev., 25, 243-256.
SMIT, J.W., SCHINKEL, A.H., WEERT, B. \& MEIJER, D.K. (1998). Hepatobiliary and intestinal clearance of amphiphilic cationic drugs in mice in which both mdrla and mdrlb genes have been disrupted. Br. J. Pharmacol., 124, 416-424.

SUGAMORI, K.S., LEE, F.J.S., PRISTUPA, Z.B. \& NIZNIK, H.B. (1999) A cognate dopamine transporter-like activity endogenously expressed in a COS-7 kidney derived cell line. FEBS Letts., 451, $169-174$.

TAMAI, I., OHASHI, R., NEZU, J-I., YABUUCHI, H., OKU, A., SHIMANE, M., SAI, Y. \& TSUJI, A. (1998). Molecular and functional identification of sodium ion-dependent, high affinity human carnitine transporter OCTN2. J. Biol. Chem., 273, $20378-20382$.

TAMAI, I., SAHEKI, A., SAITOH, R., SAI, Y., YAMADA, I. \& TSUJI, A. (1997). Nonlinear intestinal absorption of 5-hydroxytryptamine receptor antagonist caused by absorptive and secretory transporters. J. Pharmacol. Exp. Ther., 283, $108-115$.

THIEBAUT, F., TSURUO, T., HAMADA, H., GOTTESMAN, M.M., PASTAN, I. \& WILLINGHAM, M.C. (1987). Cellular localisation of the multidrug-resistance gene product P-glycoprotein in normal tissues. Proc. Natl. Acad.. Sci., 84, 7735-7738.

TIBERGHEIN, F. \& LOOR, F. (1996). Ranking of P-glycoprotein substrates and inhibitors by a calcein-AM fluorometry screening assay. Anti-Cancer Drugs, 7, 568-578.

TURNHEIM, K. \& LAUTERBACH, F.O. (1977). Absorption and secretion of monoquaternary ammonium compounds by the isolated intestinal mucosa. Biochem. Pharmacol., 26, 99-108.

UllRICH, K.J., RUMRICH, G., NEITELER, K. \& FRITZSCH, G. (1992). Contraluminal transport of organic cations in the proximal tubule of the rat kidney. Pfluegers Arch., 420, 29-38.

WU, X., PRASAD, P.D., LEIBACH, F.H. \& GANAPATHY, V. (1998). cDNA sequence, transport function and genomic organisation of the human OCTN2, a new member of the organic cation transporter family. Biochem. Biophys. Res. Commun., 246, $589-595$. 